\title{
Some Employment Dimensions of COVID-19 Recessions
}

\author{
Jomo Kwame Sundaram ${ }^{1}$
}

Published online: 10 September 2020

(c) Indian Society of Labour Economics 2020

It is misleading to say too much in general terms about the recessions unfolding in different parts of the world in the aftermath of the COVID-19 pandemic outbreak. There is not one single COVID-19 recession, but rather a variety of contractionary experiences.

There are also many reasons for the slowdowns. Some of them are quite unrelated to COVID-19, and undoubtedly, more are worse off than might otherwise have been the case because pre-existing conditions and trends have combined with the epidemic's effects, as well as both official and behavioural responses to it.

It is obviously important to recognize that unlike the last few recessions in the world, COVID-19 recessions are not primarily financially driven, although financial fragility and vulnerabilities may well worsen them.

In particular, finance has undoubtedly worsened various liquidity problems that have exacerbated the recessions. A keener contextual understanding of the role of liquidity and the nature of liquidity traps in different circumstances is crucial for designing and implementing more effective measures to efficiently provide liquidity for the variety of enterprises in the economies of developing countries.

Recessions in many countries are largely due to supply-side constraints imposed by state authorities to enforce 'stay-in-shelter' lockdowns, such as physical distancing and other precautionary requirements, including in getting to and from workplaces and other public spaces or sites (Popov and Jomo 2020).

In turn, these have undoubtedly affected aggregate demand due to their impact on livelihoods and incomes of the population. Businesses relating to many social activities, including public transportation and events, which involve close inter-personal proximity, are especially vulnerable and will require behavioural changes, at least until most people have been vaccinated or the virus threat is eradicated by some other means.

Jomo Kwame Sundaram: former UN Assistant Secretary General for Economic Development (2005-2012).

Jomo Kwame Sundaram

jomoks@yahoo.com

1 Khazanah Research Institute, Kuala Lumpur, Malaysia 


\section{Lockdown Recessions Due to Failure of Precautionary Early Actions}

COVID-19 is believed to have begun in Wuhan city in Hubei province. But even in China, lockdowns were only imposed in the three provinces around Wuhan, not in all of China. In the rest of East Asia, South Korea, Japan, Taiwan and Vietnam too, no nationwide lockdown was imposed (Nazihah and Jomo 2020). Localized lockdowns have been imposed in Vietnam, and recently in Beijing in mid-June, when and where the outbreak had spread out of control.

The WHO fact finding mission to China emphasized the need for early precautionary actions, but unfortunately, this was not acted upon in much of the world. In most of the rest of the world, especially in the West, despite the fact that knowledge of the virus and the epidemic threat was available from the new year, and the WHO declared a 'public health emergency of international concern' before the end of January, very few early precautionary measures were taken.

The use of protective face masks was actively discouraged by many national authorities, with some citing the WHO. In the UK, the view that 'herd immunity' in the population should be allowed to develop by allowing the epidemic to spread prevailed as official policy until the first Imperial College London (ICL) study was issued on March 17. Much could have been avoided if early precautionary actions were taken.

The nature of the recessions differs considerably, depending on the specific characteristics or nature of an economy, and the shares of the population differently affected due to their distribution over different types of activities and occupations as well as spatially; for example, the nature of much agricultural work is physically distanced.

For various reasons, largely due to the way the virus spreads, the crisis has especially affected urban areas, particularly where populations, residences, workplaces and social interactions tend to be more spatially concentrated. In East Asia, effective early actions - including rapid mass testing, contact tracing and informed treatment of the infected-succeeded in avoiding the need for 'stay-in-shelter' lockdowns, now often seen as the only course of action in many other countries.

While lockdown measures are arguably quite necessary, a more appropriately targeted approach would be far more effective, as in Vietnam, China and so on. And even when lockdown measures are undoubtedly necessary, they need to be better designed to address the threat of COVID-19 much more effectively.

Different types of economies, workplaces, workers, labour processes, social spaces, public transportation and so on have varying implications for spatial or physical distancing, proximate exposure and likelihood of infection. Most official attempts to save jobs have been limited to the formal sector, usually involving large enterprises.

For most developing countries, the formal sector usually accounts for a minority of the working population. Most family micro-enterprises were not very profitable, but enough to sustain livelihoods. The lockdowns have often wiped many of them out, with many others struggling to survive after extended disruption of their business turnover. 
Reduced aggregate demand has reduced labour demand generally, with the informal sector most adversely affected owing to the biased nature of governments' policy responses. Very little has been done in most of the world to save jobs, businesses and livelihoods in the informal sector. Small enterprises have not been helped in very effective ways, while most lockdown measures have involved comprehensively curbing the informal sector, while relief and recovery measures have generally been largely indifferent to their needs and problems, if not worse.

Generally constrained by market-driven fears of deficit financing (Jomo 2020), fiscal measures have largely been limited, if not eschewed, by many governments for fear of being accused of 'irresponsibly' engaging in 'deficit financing' and increasing 'public debt'. Meanwhile, the Western turn to 'unconventional monetary measures' in the last decade has influenced all too many developing countries to pursue credit and other monetary policies, eschewing bolder fiscal responses, despite differences in their circumstances.

Although many policy makers and observers use the terms interchangeably, there is a huge difference between relief and stimulus measures. Relief measures try to mitigate the adverse consequences of the recession on populations, while stimulus measures purport to contribute to economic recovery.

Furthermore, economic recovery may be conceived of as a return to the status quo ante or, alternatively, as restoring economic expansion through development and transformation (Chowdhury and Jomo 2020). Of course, relief measures may have a catalytic effect on the economy and can augment aggregate demand, amplified by multiplier effects, but analytically, it is important to estimate and not exaggerate such effects without specific analysis.

Also, there has been relatively little international solidarity in response to the COVID-19 crisis, in sharp contrast to the rhetorical responses to the 2008-2009 global financial crisis and ensuing Great Recession. It should be remembered that despite all this rhetoric at the time, protectionist trade measures were adopted by most developed economies. Hence, there has been relatively little expansion of international trade in the decade since.

In recent years, the ascendance of jingoism, or ethno-nationalism based on ethnopopulism, has attacked and at least partly reversed various dimensions of the variegated phenomena termed globalization. There has been a very significant attack on economies which had opened up to international trade and investment in some ways, including, but not limited to, participating in global supply or value chains.

US President Trump's jingoism has been central to the ongoing assault on multilateralism and plurilateralism, even including arrangements made by previous US administrations, but other jingoist regimes have more ambivalent attitudes to such arrangements. Meanwhile, US and Japanese authorities are urging 'their' companies to 'onshore' investments and productive employment, ostensibly for strategic reasons. This will significantly reduce trade and prospects for countries producing for export.

Employment generated for and by export-oriented production may have been considerable if the main motivation for investing to produce in developing countries was to lower labour costs. By reducing overall or aggregate demand, the 
COVID-19 crisis has significantly reduced commodity prices, demand for manufactured goods and the openness of the global economy.

For countries to progress in this unanticipated conjuncture, it becomes imperative to use industrial policy, i.e. the selective promotion of new investments and technologies, in order to achieve sustainable development in the foreseeable future. For many, the crisis underscores the importance of sustainable development, for example, by promoting renewable energy.

In many instances, especially where and when supply chains and production linkages were very internationally integrated, export-oriented production units were typically poorly integrated into the rest of the national economy, thus limiting their likely multiplier effects. Hence, one might find a big direct impact for those working in or for these enterprises without a significantly wider impact on the rest of the economy because of such limited integration into national economies.

Also, social protection measures are generally more institutionalized in developed welfare state economies compared to developing countries, although many social protection measures are in place in developing economies as well. It is important to recognize that financing of social protection measures 'leaks' to production as beneficiaries tend to enhance their productive and income-generating capacities when their incomes allow.

The political rise of ethno-populism in the recent period is probably the most important Western sociopolitical development of the early twenty-first century. Ethno-populism has lent support, even legitimacy to treating others, often ethnic, including cultural and religious minorities within the country as well as 'foreign aliens' outside the country as adversarial enemies to be discriminated or protected against.

There have been serious economic tensions since the beginning of the century, including those between China and President Trump in the recent period. Different powers are trying to align themselves with Donald Trump in this situation, arguably including Japan, Australia, India and Brazil.

To be sure, even before that, during Obama's presidency, for example, his administration had no interest in completing the Doha Development Round of the World Trade Organization (WTO). So, for a variety of reasons, the situation is not conducive to international cooperation or even multilateralism.

The reversal of earlier trade trends did not begin with COVID-19. In the initial period, Trump praised the Chinese response, mainly because he had concluded a deal with the Chinese to resolve a problem of his own making. Trump's political poll ratings were looking extremely good then, but have been going down since. He may turn to a more aggressive policy towards China, aligning with all major countries with outstanding problems with China such as India as well as others in East Asia.

The formal sector will be similarly hit as well by the likely shift away from the much hyped global value or supply chains. Governments, such as those of the USA and Japan, are urging 'their' transnational enterprises to be less reliant on external suppliers, especially from China, which is likely to result in much more 'onshoring' by their firms, reversing the offshoring of recent decades. 
Post-COVID-19, there has also been far more concern about food supplies, with a renewed emphasis on food security, defined in terms of greater food production and self-sufficiency, as was the case before the 1990s, rather than more recent redefinitions of food security much less concerned with reliance on food imports. Far greater emphasis should be put on nutrition, excessive antibiotic use and extensive use of toxic agricultural chemicals.

\section{References}

Chowdhury, Anis, and Jomo Kwame Sundaram. Reviving the Economy, Creating the 'New Normal'. Inter Press Service (16 June 2020), http://www.ipsnews.net/2020/06/reviving-economy-creatingnew-normal/.

Jomo Kwame Sundaram. Economic Ghosts Block Post-Lockdown Recovery. Inter Press Service (9 June 2020), http://www.ipsnews.net/2020/06/economic-ghosts-block-post-lockdown-recovery/.

Nazihah Muhamad Noor and Jomo Kwame Sundaram. East Asian Lessons for Controlling Covid-19. Inter Press Service (26 March 2020), https://www.ipsnews.net/2020/03/east-asian-lessons-controllin g-covid-19/.

Popov, Vladimir, and Jomo Kwame Sundaram. Covid-19 Recessions: This Time It's Really Different. Inter Press Service (4 June 2020), http://www.ipsnews.net/2020/06/covid-19-recessions-time-reall y-different/.

Publisher's Note Springer Nature remains neutral with regard to jurisdictional claims in published maps and institutional affiliations. 